2018

\title{
Massive Upland to Wetland Conversion Compensated for Historical Marsh Loss in Chesapeake Bay, USA
}

Nathalie W. Schieder

Virginia Institute of Marine Science

David C. Walters

Virginia Institute of Marine Science

Matthew L. Kirwan

Virginia Institute of Marine Science

Follow this and additional works at: https://scholarworks.wm.edu/vimsarticles

Part of the Earth Sciences Commons

\section{Recommended Citation}

Schieder, Nathalie W.; Walters, David C.; and Kirwan, Matthew L., Massive Upland to Wetland Conversion Compensated for Historical Marsh Loss in Chesapeake Bay, USA (2018). Estuaries and Coasts, 41(4), 940-951.

doi: $10.1007 / \mathrm{s} 12237-017-0336-9$

This Article is brought to you for free and open access by the Virginia Institute of Marine Science at W\&M ScholarWorks. It has been accepted for inclusion in VIMS Articles by an authorized administrator of W\&M ScholarWorks. For more information, please contact scholarworks@wm.edu. 


\title{
Massive Upland to Wetland Conversion Compensated for Historical Marsh Loss in Chesapeake Bay, USA
}

\author{
Nathalie W. Schieder ${ }^{1}$ • David C. Walters ${ }^{1}$ • Matthew L. Kirwan ${ }^{1}$ \\ Received: 23 November 2016 / Revised: 22 September 2017 / Accepted: 16 October 2017 \\ (C) Coastal and Estuarine Research Federation 2017
}

\begin{abstract}
Sea level rise leads to coastal transgression, and the survival of ecosystems depends on their ability to migrate inland faster than they erode and submerge. We compared marsh extent between nineteenth-century maps and modern aerial photographs across the Chesapeake Bay, the largest estuary in North America, and found that Chesapeake marshes have maintained their spatial extent despite relative sea level rise rates that are among the fastest in the world. In the mapped region (i.e., 25\% of modern Chesapeake Bay marshland), $94 \mathrm{~km}^{2}$ of marsh was lost primarily to shoreline erosion, whereas $101 \mathrm{~km}^{2}$ of marsh was created by upland drowning. Simple projections over the entire Chesapeake region suggest that approximately 100,000 acres $\left(400 \mathrm{~km}^{2}\right)$ of uplands have converted to wetlands and that about a third of all present-day marsh was created by drowning of upland ecosystems since the late nineteenth century. Marsh migration rates were weakly correlated with topographic slope and the amount of development of adjacent uplands, suggesting that additional processes may also be important. Nevertheless, our results emphasize that the location of coastal ecosystems changes rapidly on century timescales and that sea level rise does not necessarily lead to overall habitat loss.
\end{abstract}

Communicated by Nancy L. Jackson

Electronic supplementary material The online version of this article (https://doi.org/10.1007/s12237-017-0336-9) contains supplementary material, which is available to authorized users.

Matthew L. Kirwan

kirwan@vims.edu

1 Virginia Institute of Marine Science, College of William and Mary, Gloucester Point, VA 23062, USA
Keywords Marsh migration · Chesapeake Bay · Sea level rise $\cdot$ Marsh-forest boundary

\section{Introduction}

Sea level rise leads to coastal transgression, and the survival of ecosystems depends on their ability to migrate inland faster than they erode and submerge (Brinson et al. 1995; FitzGerald et al. 2008; Curray 2016). Global sea level rise rates began accelerating sharply in the late nineteenth or early twentieth century, with an approximate tripling in sea level rise rates in the last 150 years in many parts of the world (Kemp et al. 2009; Church et al. 2013). Late twentieth century relative sea level rise rates are three to four times higher along the US mid-Atlantic coast than the global average due to changes in the Gulf Stream and spatial variability in subsidence (Sallenger et al. 2012). When those changes exceed the ability of marshes and other coastal systems to adapt, ecosystems will be forced to migrate inland or submerge (Brinson et al. 1995; FitzGerald et al. 2008; Craft et al. 2009; Kirwan and Megonigal 2013). Accelerated sea level rise therefore threatens tidal marshes and other coastal environments, which are well known for ecosystem services such as carbon sequestration, storm protection, and nutrient transformation (Barbier et al. 2011).

Feedbacks between flooding, plant growth, and sediment deposition allow marshes to adapt to changes in sea level in the vertical dimension. Increases in flooding duration tend to enhance sediment deposition on the marsh surface, plant productivity, soil building, and marsh elevation gain (Reed 1995; Friedrichs and Perry 2001; Cahoon et al. 2006; Kirwan and Megonigal 2013; Kirwan et al. 2016a). However, the strength of this feedback depends fundamentally on the availability of mineral sediments, so that marshes in sediment deficient areas 
remain vulnerable to sea level rise (Kirwan et al. 2010; Day et al. 2011; D'Alpaos et al. 2012; Weston 2014). Marshes are fundamentally unstable in the lateral dimension, where erosion of marsh edges is a primary contributor to marsh loss even in the absence of sea level rise (Fagherazzi et al. 2013). Marsh erosion rates typically vary between $\sim 0.1$ and $3 \mathrm{~m}$ year $^{-1}$, depending on wave power, the elevation of marsh relative to water level, and vegetation-mediated soil strength (Schwimmer 2001; Mariotti and Fagherazzi 2010; Gedan et al. 2011; Fagherazzi et al. 2013; McLoughlin et al. 2015; Ford et al. 2016; Silliman et al. 2016). Accelerations in the rate of sea level rise potentially enhance erosion rates by increasing water depth, wave height, and the height of the marsh-tidal flat scarp (Mariotti and Fagherazzi 2010; Marani et al. 2011).

Marshes also respond to sea level rise by migrating inland and replacing terrestrial ecosystems (Brinson et al. 1995; Raabe and Stumpf 2015; Kirwan et al. 2016a). Progressive flooding leads to the development of wetland soils and vegetation (Hussein 2009; Anisfeld et al. 2016). In coastal forests, inundation and salt stress lead to seedling mortality so that forests do not regenerate following the death of adult trees during storms or other events (Clark 1986; Williams et al. 1999; Kirwan et al. 2007). These processes allow new marshes to form along a moving upland boundary as a function of the rate of sea level rise and upland slope (Brinson et al. 1995; Hussein 2009; Smith 2013; Raabe and Stumpf 2015). Upland to wetland conversion has been described along the margin of many marshes throughout North America and is thought to be important to future marsh survival at regional scales along the Gulf and mid-Atlantic coasts (Doyle et al. 2010; Feagin et al. 2010; Morris et al. 2012; Smith 2013; Raabe and Stumpf 2015; Clough et al. 2016; Enwright et al. 2016). However, steep topography and anthropogenic barriers commonly limit marsh migration in other places (Feagin et al. 2010; Kirwan and Megonigal 2013; Torio and Chmura 2013; Wasson et al. 2013; Enwright et al. 2016; Field et al. 2016).

The vulnerability of marshes to sea level rise therefore depends at least in part on the competition between erosion and migration, but it is unclear how the balance between these processes has changed historically, or will change under accelerated rates of sea level rise in the future. Previous work focuses largely on either erosion or migration alone and suggests that both processes may accelerate in parallel with sea level rise (Hussein 2009; Mariotti and Fagherazzi 2010; Kirwan et al. 2016b). Recent work along a portion of the Florida Gulf Coast suggests migration into uplands has exceeded historical erosion rates (Raabe and Stumpf 2015), and modeling proposes that marsh migration rates are more sensitive to sea level rise than edge erosion rates (Kirwan et al. 2016a). These observations suggest a counter-intuitive expansion of marshes with sea level rise along undeveloped coasts, but this idea remains largely untested, especially at regional scales with large human populations that may present barriers

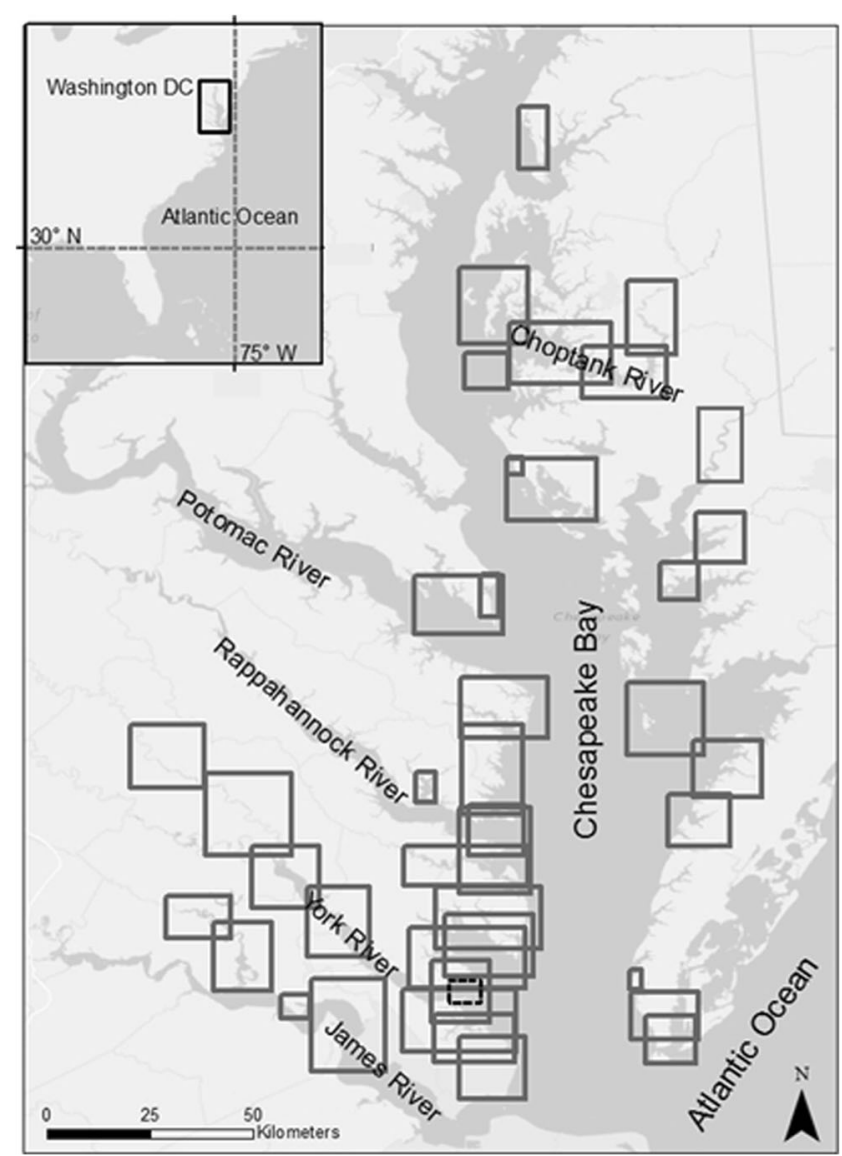

Fig. 1 Study area map of the Chesapeake Bay region showing the major rivers, the extent of individual T-sheets used in the analysis (gray rectangles), and area displayed in Fig. 2 (dashed rectangle)

to migration. Here, we compare the extent of marshes from nineteenth-century maps of the Chesapeake region to modern imagery and find that marsh migration into adjacent uplands has allowed Chesapeake marshes to survive the fastest relative sea level rise rates on the Atlantic coast.

\section{Methods}

\section{Regional Setting}

This study concentrates on the marshes and low elevation coastal region surrounding the Chesapeake Bay, the largest coastal-plain estuary in North America (Fig. 1). Chesapeake Bay is a classic, drowned river valley estuary, with microtidal tides, and a total watershed area of approximately 166,000 km² (Perry et al. 2001; Chesapeake Bay Program 2015). Marshes occupy about $1200 \mathrm{~km}^{2}$ of the Chesapeake region (Stevenson et al. 1985; Chesapeake Bay Program 2015), including approximately $20 \%$ of the Chesapeake Bay shoreline (Rosen 1980). Typical vegetation communities in regularly flooded marshes include Spartina alterniflora and Schenoplectus americanus, and irregularly flooded marshes 
Fig. 2 Example of land type delineation and change analysis. a T-sheet from the mouth of the York River from 1853 (T00496) showing water, marsh, forest, agriculture, and developed upland land types. b Aerial photograph from 2013 was compared to historical maps to determine the amount of marsh area lost due to edge erosion and gained due to upland retreat. c Simplified map representing the historical change in marsh area
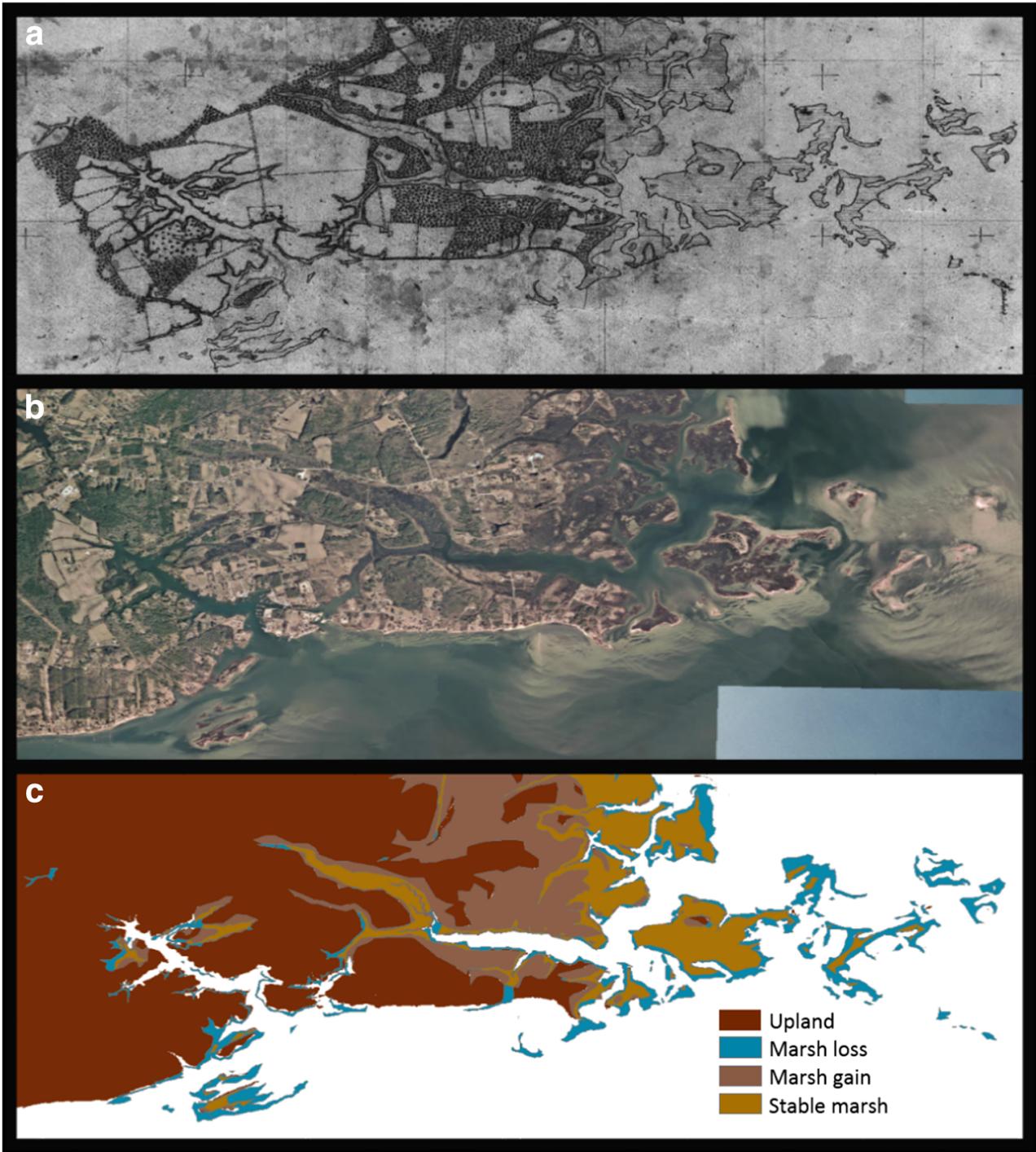

include Spartina patens, Distichlis spicata, and Juncus romerianus. Adjacent low-gradient uplands are dominated by Pinus taeda and Juniperus virginiana, and the marshforest transition zone typically includes Phragmites australis, Iva frutescens, and Myrica cerifera (Perry et al. 2001; Kirwan et al. 2007).

Historical relative sea level rise rates in the Chesapeake Bay range between 3 and $6 \mathrm{~mm}$ year ${ }^{-1}$ (http:// tidesandcurrents.noaa.gov/sltrends/sltrends.html) and are about twice as fast as eustatic sea level rise rates as a result of subsidence (1.6-2.0 mm year ${ }^{-1}$ ) (Engelhart et al. 2009). Relative sea level rise in the Chesapeake Region has accelerated from 1 to $3 \mathrm{~mm} \mathrm{year}^{-1}$ in the $1930 \mathrm{~s}$ to $4-10 \mathrm{~mm}_{\text {year }}{ }^{-1}$ in 2011 due to climate warming and changes in ocean currents (Ezer and Corlett 2012; Sallenger et al. 2012). Coastal ecosystems are rapidly transgressing in response to sea level rise, characterized by erosion of salt marsh edges, mortality of low elevation forests, and migration of marshes into adjacent uplands (Brinson et al. 1995; Hussein 2009).

\section{Habitat Mapping}

To determine how the size and location of marshes in the Chesapeake region have responded to historical sea level rise, we compared the spatial distribution of marshes from nineteenth-century era maps to modern aerial photographs (Fig. 2). We located 66, 1:20,000 scale, NOS topographic sheets ("T-sheets") from the years 1846 to 1912 that included information on simple land types (e.g., marsh, farmland, forests) from the tidal portions of the Chesapeake Bay and its tributaries (NOAA Shoreline Website 2015). T-sheets from this time period were created by plane tables and focused on the coastline as well as its plane geometry (Shalowitz 1964). We discarded 26 maps that did not clearly distinguish between 
marsh and forested areas due to poor map quality, inconsistent symbology, and ambiguous treatment of forested wetlands. To build consistency between different standards of individual surveyors, we did not include maps with no clear delineation between upland and marsh. We georeferenced each historical T-sheet to modern aerial photographs in ArcGIS by locating approximately 10 control points (e.g., road intersections, creeks) that were visible in both sets of images, and fitting with first- or second-order polynomial. We calculated the root mean square error (RMSE) associated with georeferencing and discarded maps with RMSE greater than $15 \mathrm{~m}$. Average RMSE of the remaining 40 maps was $6-7 \mathrm{~m}$. This error is similar to that reported for T-sheets in previous work (Raabe and Stumpf 2015). The remaining historical maps represented all sections of the Bay, though maps were most abundant in the southwestern portion of the bay (Fig. 1).

We compared the T-sheets with 6-inch resolution orthoimagery from Maryland collected in 2013 (Eastern Shore of Chesapeake Bay) and 2014 (Western Shore) (http:// imap.maryland.gov/Pages/imagery-products.aspx) and orthoimagery from Virginia collected in spring 2013 (ArcGIS server gismaps.vita.virginia.gov). Tidal marshes were digitized by hand by tracing the boundary between marsh and open water and the boundary between marsh and upland. The marsh-forest boundary was identified as the line between the dense tree canopy and marsh, and the marshwater boundary was identified as the line between open water and adjacent land excluding beaches. Because the resolution of the modern photographs was significantly better than the Tsheets, we delineated the modern marsh at the same scale as the historical T-sheets $(1: 20,000)$. This treatment eliminated interior ponds and many narrow $(<15 \mathrm{~m})$ fringe marshes that were discernable along channels in modern imagery but not in the T-sheets. The minimum size of marshes and forest patches delineated on the T-sheets was about $350 \mathrm{~m}^{2}$, and we were careful to delineate patches of similar minimum size on the modern imagery. This approach allows marsh delineation over large spatial scales, builds consistency between highresolution modern imagery and low-resolution historical maps, and ensures that measured changes in marsh area are not an artifact of changes in map quality.

\section{Analytical Methods}

To summarize changes in marsh area through time, we calculated historic and modern marsh area for each T-sheet individually, where rates refer to the change in area divided by the number of years between 2013 and the year of the T-sheet. We derived linear rates of change by dividing the area of marsh change by the modern shoreline length, defined as the length of the water-marsh boundary for edge erosion rates, and the length of the marsh-forest boundary for migration rates. The shoreline length was calculated directly from previously established marsh polygons and was therefore determined at the same scale $(1: 20,000)$ so that it included only large creeks (>30 m wide). Finally, we summarized changes in marsh area across watersheds of the major river systems in the Chesapeake region defined by USGS HUC 4 watershed boundaries (USGS Watershed Boundary Dataset: http://nhd. usgs.gov/wbd.html). For portions of the watershed with overlapping T-sheets, we generally used the T-sheet with the lowest georeferencing error. Changes in marsh area by watershed were aggregated to determine total, bay-wide changes.

Our methods explicitly calculate areas of marsh gain and loss along the seaward and landward margins of the historic and modern marsh extent and assume that positive changes in marsh area at the upland boundary are due to migration into retreating uplands, whereas negative changes in marsh area at the seaward boundary are due to marsh edge erosion. Total net change in marsh size is calculated as the difference between the area of marsh migration and marsh shoreline erosion. Thus, our approach focuses on large-scale drivers of marsh gain and loss, rather than more subtle changes such as expansion of small, interior ponds. We tested these key assumptions by re-mapping four randomly selected, but representative, map units in different portions of the Chesapeake region (T02957, T01534I, T00199, T00686 in Supplementary Table 1). For each map, we manually compared the causes of marsh loss and gain. On average, $96 \%$ of marsh gain resulted from marsh migration into adjacent uplands, whereas $4 \%$ resulted from progradation into open water. $98 \%$ of marsh loss resulted from marsh edge erosion, whereas $2 \%$ resulted from woody encroachment and conversion to anthropogenic land uses. Total marsh loss across the four map units did not depend on the spatial resolution of mapping $\left(61.4 \mathrm{~km}^{2}\right.$ at $1: 20,000 ; 62.8 \mathrm{~km}^{2}$ at $1: 1000$ ) because small interior ponding visible on the modern imagery was only responsible for about $2 \%$ of total marsh loss. Since the vast majority of marsh gain and loss was caused by migration and shoreline erosion, those terms are hereafter used interchangeably.

We characterized the slope and land cover of uplands within a 100-m buffer of delineated marshes in an effort to understand potential factors influencing rates of marsh migration. The slope of adjacent uplands was determined from LiDARderived bare earth digital elevation models flown between 2010 and 2012 at a resolution of $2.5 \times 2.5 \mathrm{ft}$ (Virginia Lidar 2015) and between 2014 and 2015 at a resolution of $1 \times 1 \mathrm{~m}$ (ESRGC 2015). For each pixel within the buffered upland region, we extracted elevation from the digital elevation model and used the Euclidean distance tool in ArcGIS to determine distance from the modern marsh-upland boundary and then used linear regression to calculate an average upland slope. We used the NLCD 2011 Land Cover map (MultiResolution Land Characteristics Consortium 2016) to estimate potential anthropogenic barriers to marsh migration. Typical anthropogenic barriers to wetland migration in the 
Chesapeake region include roads, bulkheads, and small berms and revetments. These features are not consistently identifiable near the upland boundary, so we assume that the fraction of developed land is a proxy for anthropogenic barriers, where highly developed land would have more extensive barriers to marsh migration. Landscape-scale models of marsh migration commonly assume that migration will only occur into forested uplands. Therefore, we defined developed uplands as land that was classified as urban or agricultural, and calculated the ratio of developed land to total land area within the buffered upland region. Rates of marsh migration were then compared to characteristics of the adjacent uplands (i.e., slope and degree of development) for each map using linear and multiple regression.

\section{Results}

The total extent of tidal marshes in the studied portion of the Chesapeake Bay region was nearly identical in nineteenth-century historical maps and modern aerial photographs. The nineteenth-century T-sheet maps included $311 \mathrm{~km}^{2}$ of tidal marshes, and the same mapping area included $318 \mathrm{~km}^{2}$ of marshes in 2013 (Supplementary Table 1). Marsh area change at the marsh-water boundary was negative in each map unit (defined as the extent of individual T-sheets), indicating that erosion was greater than marsh progradation into open water, and is likely the dominant driver of marsh loss in our study (Supplementary Table 1). Marsh area change at the marsh-upland boundary was positive in each map unit, indicating that marsh migration into uplands was greater than apparent woody encroachment into marshes that could potentially result from classification errors in the nineteenth-century maps (Supplementary Table 1). Marsh gain slightly exceeded loss in the James River and Eastern Shore watersheds, whereas loss slightly exceeded gain in the York River watershed (Fig. 3). Summed across the entire mapped area, new marsh created at the migrating upland edge $\left(101 \mathrm{~km}^{2}\right)$ compensated for marsh loss at the marsh-water boundary $\left(94 \mathrm{~km}^{2}\right)$, resulting in a total net marsh expansion of about $7 \mathrm{~km}^{2}$ or $2 \%$ (Fig. 3). The total mapped area represents $24 \%$ of all marshes in the Chesapeake Bay and its tributaries (1200 km²) (Stevenson et al. 1985; Chesapeake Bay Program 2015). The slope of the upland topography within a $100-\mathrm{m}$ buffer of marshes in the mapped area $(0.03 \pm 0.02)$ is similar to the slope of adjacent uplands in the entire Chesapeake region $(0.05 \pm 0.08)$, suggesting that our upland submergence rates may be generally representative. Therefore, simple projections across the entire Chesapeake region imply that more than 100,000 acres $\left(400 \mathrm{~km}^{2}\right)$ of uplands has converted to wetlands over the last century.

Despite little net change in marsh area summed across the entire Chesapeake region, net change in marsh extent differed widely between individual map units (Supplementary Table 1). For example, a maximum loss of $\sim 90 \%$ of marshes was observed for the Cape Charles, VA T-sheet extent, and a maximum gain of $\sim 400 \%$ was observed for the Potomac River, MD T-sheet extent. Sixteen of 40 maps had marsh loss rates exceeding 10\%, 15 maps had expansion rates exceeding $10 \%$, and only 10 maps showed net change rates of less than $10 \%$. The average rate of marsh migration for individual map units was $0.49 \pm 0.36 \mathrm{~m} \mathrm{year}^{-1}$ (SD) with the highest migration rates occurring on the eastern shore of the Chesapeake Bay and the mouth of the York River (Fig. 4a). The lowest marsh migration rates appear along the Chesapeake tributaries and in the middle fractions of the bay. The average erosion rate was $0.53 \pm 0.42 \mathrm{~m}_{\text {year }}{ }^{-1}(\mathrm{SD})$, with the fastest rates peaking along the Rappahannock River as well as the Choptank River area and the lowest rates appearing along the eastern shore of Virginia and the Chickahominy River (Fig. 4b). In general, net marsh expansion occurred
Fig. 3 Changes in marsh area resulting from marsh migration into drowned uplands (stripes), edge erosion (dots), and net change (migration minus erosion) (solid fill) summarized by watershed

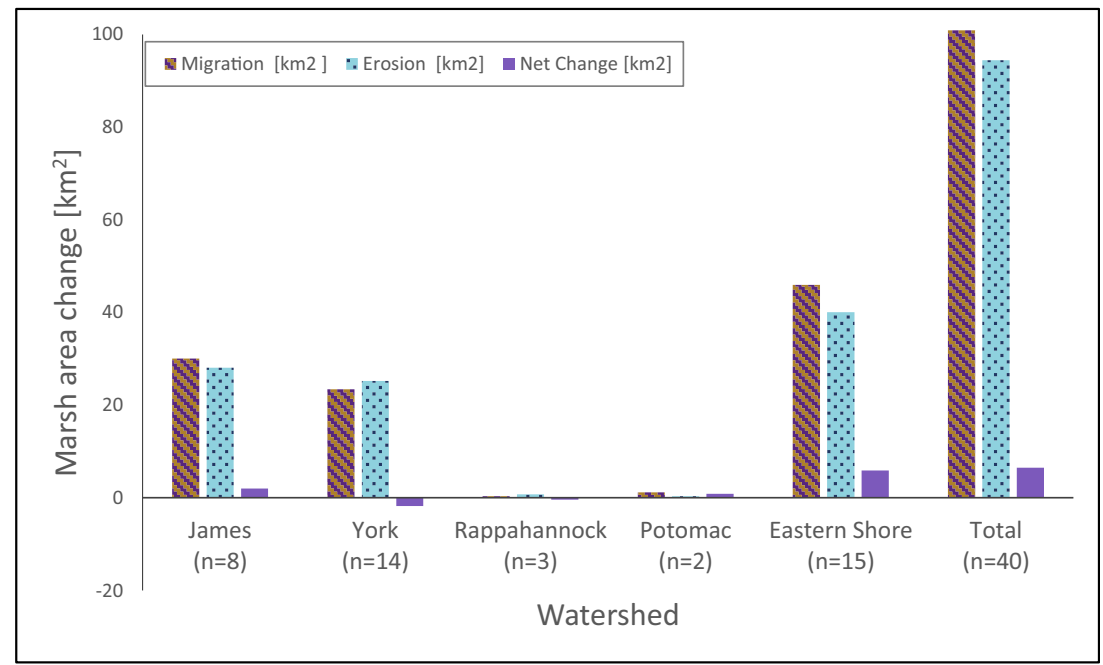


primarily in the southern part of the Chesapeake Bay, whereas marsh contraction occurred mostly in the mid and northern Bay and on islands with limited potential for marsh migration (Fig. 4c). These results are broadly consistent with previous work demonstrating marsh loss in the mid Bay (e.g., Stevenson et al. 1985; Kearney et al. 1988; Schepers et al. 2017), rapid erosion of Chesapeake Bay islands (Kearney and Stevenson 1991), and localized marsh expansion in the lower bay (Kirwan et al. 2016b).

Marsh migration rates were weakly correlated with characteristics of adjacent uplands. The average upland slope within $100 \mathrm{~m}$ of the modern marsh was 0.03 and varied between 0.004 and 0.1 between map units (Supplementary Table 1). Low upland slopes were located along the eastern shore of Virginia (e.g., Nandua Creek map $=0.003$ ), and the highest slopes were generally located near the heads of rivers (e.g., Choptank River map $=0.1$ ). Simple linear regression indicated a weak relationship between rate of marsh migration and upland slope $\left(r^{2}=0.16 ; p<0.05\right)$ (Fig. 5a).

The average land use within $100 \mathrm{~m}$ of the modern marsh was $41 \%$ forest, $26 \%$ urban, and $22 \%$ agriculture. Developed land (urban plus agriculture) averaged over individual map units ranged from $3 \%$ developed to $79 \%$ developed within the buffer. Simple linear regression indicated a weak relationship between marsh migration rate and the fraction of uplands developed $\left(r^{2}=0.09 ; p=0.05\right.$ ) (not shown), and that migration rate was weakly related to upland slope even in the most undeveloped uplands (development $<10 \%)\left(r^{2}=0.19 ; p=0.07\right)$ (Fig. 5b).

\section{Discussion}

\section{Reliability of Historical Maps}

Nineteenth-century T-sheet maps are commonly used to reconstruct changes in the position of shorelines, barrier islands, marshes, mangroves, and coastal forests, where they are considered to be an effective baseline dataset on which to measure subsequent change (e.g., Douglas and Crowell 2000; Moore 2000; Krauss et al. 2011; Raabe and Stumpf 2015). Delineation of the marsh-upland boundary on T-sheets is more uncertain than delineation of shorelines, as it depended on site accessibility and interpretations of individual surveyors (Shalowitz 1964; Moore 2000). Nevertheless, historical changes in the position of the marsh-upland boundary have been reconstructed on the basis of nineteenth-century T-sheet maps, where previous work noted that maps were generally consistent with aerial imageries and soil samples (Collins and Sheikh 2005; Raabe and Stumpf 2015). The average RMSE of the 40 maps analyzed here $(6-7 \mathrm{~m})$ is similar to that reported in other T-sheet-based studies of marsh extent (e.g., $\sim 8 \mathrm{~m}$ (Wrayf et al. 1995), 6-20 m (Collins and Sheikh 2005), $4.6 \mathrm{~m}$ (Raabe and Stumpf 2015)). The combined error in the $x$ and $y$ directions $\left(7 \mathrm{~m} \times 7 \mathrm{~m}=0.000049 \mathrm{~km}^{2}\right)$ is several orders of magnitude less than observed changes in marsh area for an individual T-sheet $\left(\sim 1 \mathrm{~km}^{2}\right)$ (Supplementary Table 1 ), and changes in land type are generally parallel to shorelines or elevation contours, rather than the type of systematic offset that might be expected for a georeferencing error.

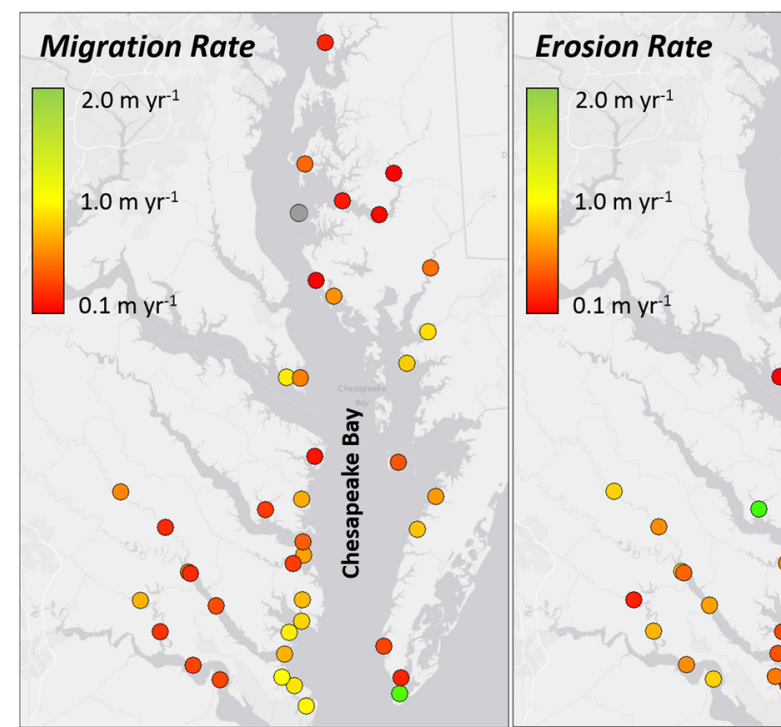

Fig. 4 Marsh migration rates ( $\mathrm{m}_{\text {year }}{ }^{-1}$ ), erosion rates $\left(\mathrm{m} \mathrm{year}^{-1}\right)$, and net change in area (\%) along the Chesapeake Bay. Each circle represents an individual T-sheet, where reported values represent the change averaged over the entire T-sheet extent. Green colors denote rapid change and red colors denote slow change, except for in the "Net Change" panel where

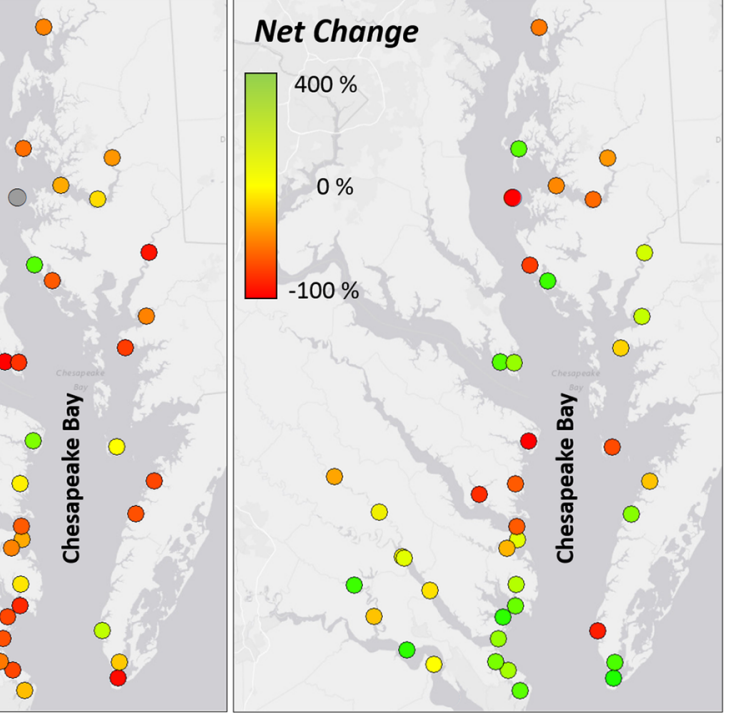

green indicates net marsh expansion (migration $>$ erosion) and red indicates net marsh loss (erosion $>$ loss). The gray dot represents Sharps Island and does not have a migration or erosion rate because complete land loss occurred prior to 2013 


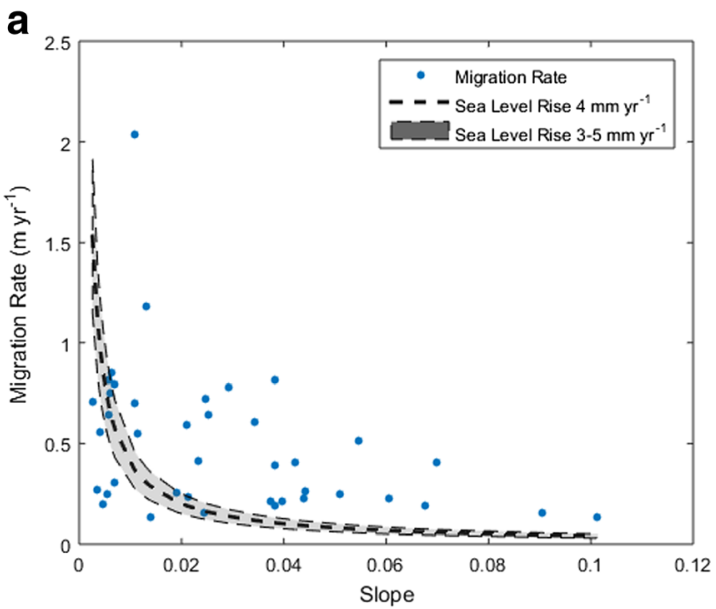

Fig. 5 Historical marsh migration rate versus characteristics of adjacent uplands, where each marker represents the average migration rate and topographic slope across an individual T-sheet extent. Characterization of adjacent uplands is restricted to a 10-m buffer around the modern marsh-upland boundary. a Observed migration rates (blue markers) compared to expected migration rates for historical relative sea level rise rates of 3,4 , and $5 \mathrm{~mm} \mathrm{year}^{-1}$ (gray envelope). Observed migration rates are less than the expected migration rate, which is defined as the sea level rise rate divided by slope (i.e., $y=R / m$ ). Observed migration rates are weakly

Several observations suggest nineteenth-century Tsheets are suitable for reconstructing historical marsh change and the position of the marsh-upland boundary, in the Chesapeake region. Rates of erosion and marsh migration into uplands at Goodwin Island, VA (lower Chesapeake Bay) based on aerial photographs are similar to rates determined from $\mathrm{T}$-sheets at the same location. Aerial photograph analysis indicates erosion and migration rates of 0.25 and $0.5 \mathrm{~m} \mathrm{year}^{-1}$ from 1937 to 2011 (Kirwan et al. 2016b), and the T-sheet analysis indicates erosion and migration rates of 0.26 and $0.35 \mathrm{~m} \mathrm{year}^{-1}$ between 1853 and 2013 (this study). The slight difference in migration rate reflects increasing migration rates through time in response to accelerated sea level rise (Kirwan et al. 2016b). The location of the forest-marsh boundary on T-sheets is also consistent with historical maps and sediment cores from a site in the upper Chesapeake Bay. Figure 6 shows the position of the historical forest-marsh boundary near Hell Hook marsh from multiple map sources, which is a site where forest retreat has been independently reconstructed through sediment coring (Hussein 2009). The resulting map shows the expected gradual inland migration of the marsh-forest boundary through time. The marsh-forest boundary in the 1848 T-sheet is similar to an 1864 map and slightly seaward of the 1898 and 1905 maps. Dated sediment cores show the same gradual inland migration of the marsh-forest boundary (Hussein 2009). The sediment core with a dated 1848 forest-marsh transition is located approximately $58 \mathrm{~m}$ inland of the $1848 \mathrm{~T}$-sheet boundary,

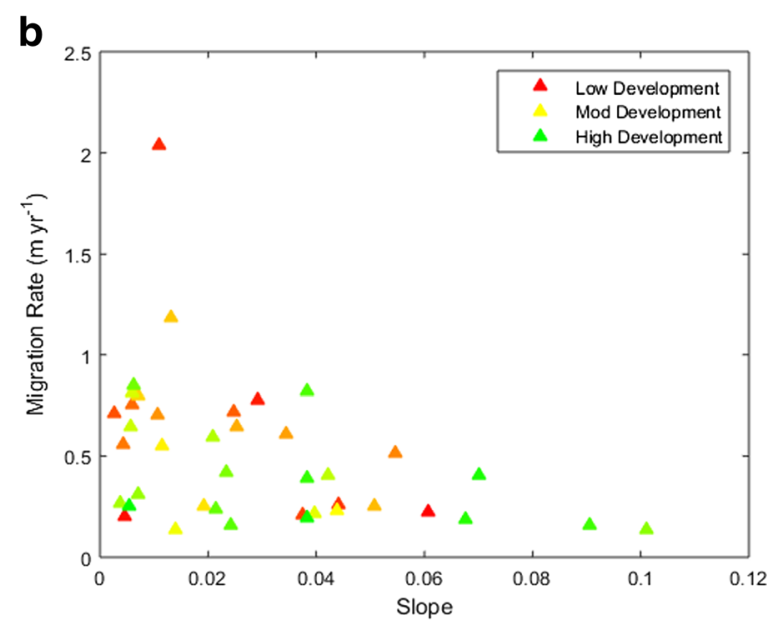

correlated with topographic slope $\left(y=-6.0034 x+0.6673, r^{2}=0.16\right.$, $p<0.05)$ and are not significantly correlated with expected migration rates $\left(y=0.2206 x+0.4195, r^{2}=0.04, p>0.1\right)$. b Observed migration rates as a function of topographic slope and intensity of coastal development in adjacent uplands. Coastal development includes agricultural and urban land uses, and colors reflect a gradient in development from low (red) to high (green). There is a weak correlation between slope and migration rate in uplands with lowest development $(<10 \%)$ $\left(y=-10.233 x+0.8828, p=0.07, r^{2}=0.19\right)$

but the two metrics are perhaps consistent given that sediment cores reflect the development of wetland soils that may occur under living trees, and therefore pre-date the retreat of mapped forests. In any case, migration rates over century timescales (1848-1905 to 2013) are similar whether derived from boundaries inferred from the 1848 sediment core $\left(2.1 \mathrm{~m}^{-1} \mathrm{yer}^{-1}\right)$, the $1848 \mathrm{~T}$-sheet $\left(2.4 \mathrm{~m} \mathrm{year}^{-1}\right)$, or maps from $1864\left(2.8 \mathrm{~m} \mathrm{year}^{-1}\right), 1898$ $\left(2.8 \mathrm{~m} \mathrm{year}^{-1}\right)$, or $1905\left(2.1 \mathrm{~m} \mathrm{year}^{-1}\right)$. Therefore, multiple lines of evidence in two disparate locations within the Chesapeake study region all suggest that T-sheets are reliable for mapping century-scale forest retreat.

Finally, we note that inconsistent mapping of the marshupland boundary is not itself a critical issue for our goal of resolving total changes in marsh area across the entire Chesapeake region because errors in one direction on some maps would be balanced by errors in the other direction on other maps. A much more serious problem would be consistent, systematic error (i.e., the marsh-upland boundary consistently mapped too far inland or too far seaward) in every Tsheet. Our observation of no upland encroachment into marshes (Supplementary Table 1) helps rule out systematic error associated with mapping the boundary too far inland, while our observation of gradual upland retreat through time (Fig. 6) helps rule out systematic error associated with mapping the boundary too far seaward. Though these observations suggest that historical T-sheets are generally reliable, we caution that it may be difficult to distinguish between no net change and slight marsh expansion summed across the entire Chesapeake Bay. 


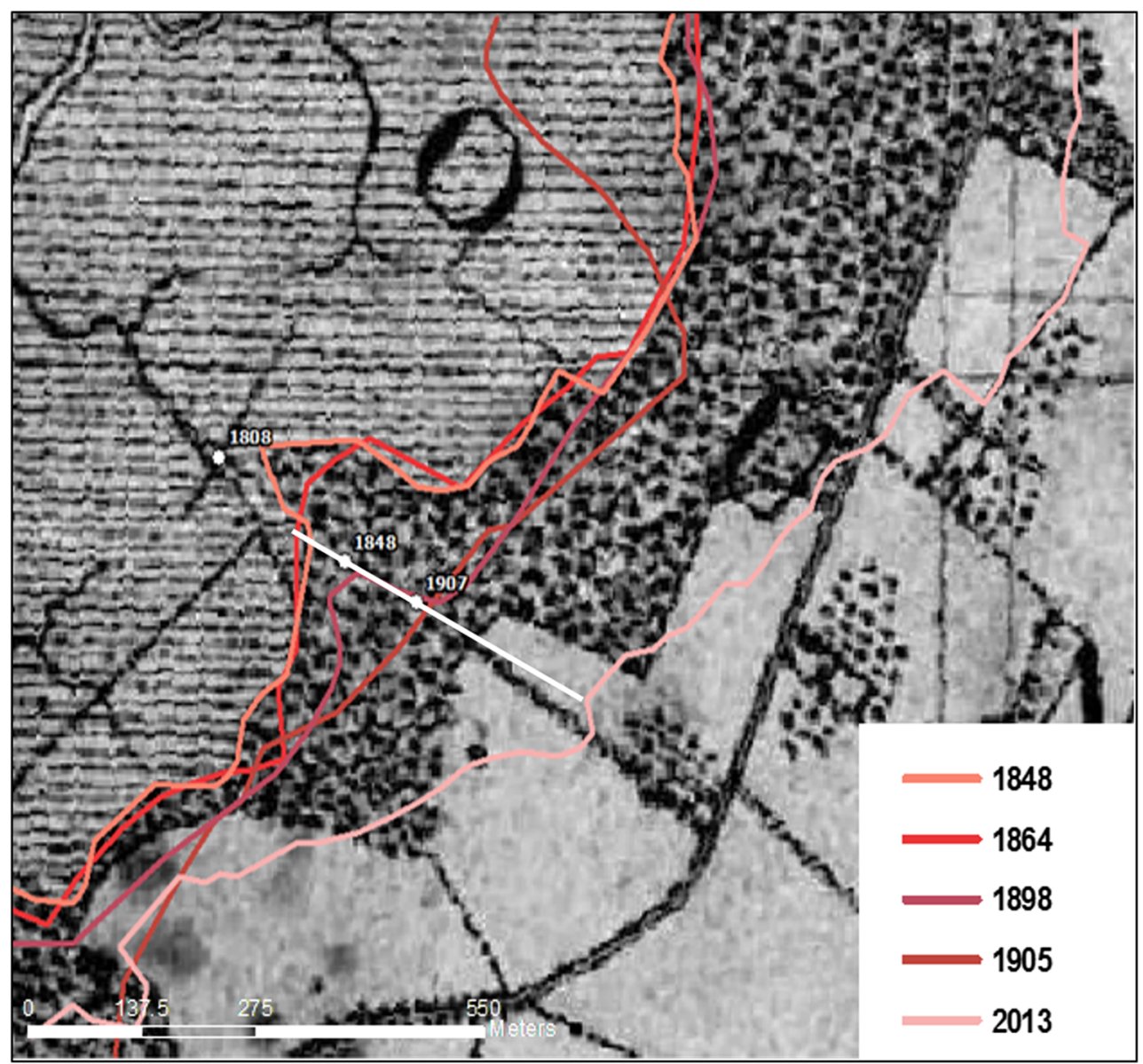

Fig. 6 Movement of the marsh-forest boundary derived from historical maps and sediment cores (lines $=$ maps, dots $=$ sediment cores). The 1848 line represents the T-sheet boundary [T00255] used in the analysis. The 1898 and 1905 lines are from USGS topographic maps, and the 1864 line

\section{Chesapeake Bay Marsh Erosion and Migration}

Our finding that marshes have historically maintained or slightly increased their spatial extent in response to rapid sea level rise (Fig. 3) contrasts with previous work that identifies Chesapeake marshes as highly vulnerable to sea level rise. Expansive marshland along the Blackwater River, for example, is well recognized to be submerging and eroding (Stevenson et al. 1985; Kirwan and Guntenspergen 2012; Ganju et al. 2013; Schepers et al. 2017), with a total loss of about $20 \mathrm{~km}^{2}$ since the 1930s within the Blackwater National Wildlife Refuge (Stevenson et al. 1985; Scott et al. 2009). Extensive marsh loss has also been reported along the Nanticoke River (Kearney et al. 1988). There are no Tsheets of suitable quality along the Blackwater River, which means our analysis likely underestimates historical marsh loss. However, $4 \mathrm{~T}$-sheets located in similar areas on adjacent rivers, including the Nanticoke River, actually show net marsh expansion despite substantial erosion because upland drowning is rapid in this low-relief region (Supplementary Table 1; $17 \mathrm{~km}^{2}$ erosion; $23 \mathrm{~km}^{2}$ upland drowning; T00270, T00268-1, is from the US Coast Survey, Coast Chart Number 33. The dots represent the location of the marsh-forest boundary inferred from dated sediment cores (Hussein 2009), and the white line indicates a transect over which forest retreat rates were measured

T00255, T00266). Aerial photograph analysis within the Blackwater National Wildlife Refuge indicates net marsh loss since 1938, but that marsh migration into drowned uplands $\left(12 \mathrm{~km}^{2}\right)$ compensated for more than half of the marsh area that was lost due to conversion to open water $\left(20 \mathrm{~km}^{2}\right)$ (Scott et al. 2009).

Across the entire Chesapeake region, remote sensing suggests that approximately $70 \%$ of marshes are currently degraded (Kearney et al. 2002). Expert opinion assessments predict major loss of Chesapeake marshes even for slight increases in sea level rise rates (Reed et al. 2008), and SLAMM modeling predicts a $36 \%$ loss of marshes with a $0.69 \mathrm{~m}$ SLR by 2100 (Glick et al. 2008). More generally, Chesapeake marshes are considered highly vulnerable to sea level rise because marshes in low tidal range estuaries have a narrow range of elevations that vegetation can survive and low maximum rates of vertical accretion (Kirwan et al. 2010; D'Alpaos et al. 2012; Balke et al. 2016).

Important limitations of this study and previous studies likely explain why historical mapping reveals regional stability of Chesapeake marshes in a system well recognized to be 
vulnerable to sea level rise. Previous work along the Blackwater and Nanticoke rivers identifies rapid marsh loss that occurs primarily by the expansion of interior ponds (Stevenson et al. 1985; Kearney et al. 1988; Schepers et al. 2017). However, our T-sheet-based reconstructions measure the overall size of marshes between uplands and major water features such as a bay or channel and cannot capture the loss of interior marshland due to ponding. Therefore, it is entirely possible that expanding marshes are simultaneously becoming more dissected with ponds and small tidal creeks, so that marsh size is not necessarily an indicator of vegetated area or marsh health. On the other hand, the large spatial domain of our study uniquely indicates that marsh loss in some parts of the Chesapeake region (e.g., Blackwater and Nanticoke rivers (Stevenson et al. 1985; Kearney et al. 1988; Beckett et al. 2016)) has been at least partially compensated by the creation of new marsh elsewhere (e.g., southwestern Bay) (Fig. 4). Site-specific research focused on hotspots of marsh loss, and vulnerability assessments based on rates of vertical soil building, therefore underestimate the major contribution upland migration makes to marsh stability in the face of sea level rise.

Our regional-scale estimates of Chesapeake Bay marsh erosion $\left(0.53 \mathrm{~m} \mathrm{year}^{-1}\right)$ and migration $\left(0.49 \mathrm{~m} \mathrm{year}^{-1}\right)$ rates are similar to reported rates. Reported rates of erosion from individual marshes typically vary from $\sim 0.1$ to $>3 \mathrm{~m} \mathrm{year}^{-1}$ (Fagherazzi et al. 2013). At the regional scale, average shoreline erosion rates have been reported for the Virginia portion of the Chesapeake Bay (0.21 m year ${ }^{-1}$ (Byrne and Anderson 1978); $0.54 \mathrm{~m} \mathrm{year}^{-1}$ (Rosen 1980)), Albemarle-Pamlico Sounds ( $0.3 \mathrm{~m} \mathrm{year}^{-1}$ (Corbett et al. 2008), $0.91 \mathrm{~m} \mathrm{year}^{-1}$ (Soil Conservation Service 1975), $1 \mathrm{~m} \mathrm{year}^{-1}$ (Riggs 2001)), the Delaware Bay (3.21 $\mathrm{m} \mathrm{year}^{-1}$ (Phillips 1986)), and the Big Bend region of the Florida Gulf Coast (1.2 $\mathrm{m}$ year $^{-1}$ (Raabe and Stumpf 2015)). Although many differences between methods and study sites could be responsible for the disparity, our reported erosion rates are likely lower than the majority of previously estimated rates because we include many marshes adjacent to tidal channels with fetches that are too small to generate wave-driven erosion, whereas most previous work focused on erosion along the estuary edge and major tributaries. Reported rates of marsh migration into uplands vary from about 0.5 to $6.8 \mathrm{~m} \mathrm{year}^{-1}$ (Hussein 2009; Smith 2013; Raabe and Stumpf 2015; Kirwan et al. 2016a). The highest rates (3.5-6.8 $\mathrm{m} \mathrm{year}^{-1}$ (Hussein 2009)) are calculated from individual transects in locations selected specifically to study rapid marsh migration, whereas our rates also include large parts of the landscape with no migration. At the regional scale, our reported migration rates are likely lower than those observed along the Florida Coast $\left(2.3 \mathrm{~m} \mathrm{year}^{-1}\right)$ because we measured the length of the marsh-upland boundary at the 1:20,000 scale and therefore included crenulations, islands, and many other features that would have been excluded in a more generalized approach (Raabe and Stumpf 2015). Nevertheless, linear rates of marsh erosion and migration are highly sensitive to the complexity of the topography and the scale at which shoreline length is measured.

\section{Broader Implications}

Marsh migration rates into adjacent uplands are widely considered to be proportional to topographic slope and the rate of sea level rise (Brinson et al. 1995; Hussein 2009; Doyle et al. 2010; Raabe and Stumpf 2015; Kirwan et al. 2016b). We found that historical marsh migration rates were weakly correlated with slope and were highly variable compared to the migration rate that would be predicted on the basis of slope and historical sea level rise rate (i.e., migration $=R / \mathrm{m}$ ) (Fig. $5 a)$. Ecological lags and/or interactions with human development may explain the weak correlation. Adult trees are resilient to sea level impacts, so that retreat of coastal forests takes place only after punctuated disturbance events such as major hurricanes (Clark 1986; Williams et al. 1999; Kirwan et al. 2007; Poulter et al. 2008; Field et al. 2016). Even if marsh vegetation was colonizing under live trees, marsh migration could not be measured from aerial photographs until the death of canopy trees, which introduces a lag between sea level rise and observed marsh migration. Migration rates may also be weakly correlated with slope because anthropogenic barriers commonly prevent migration. Previous work focused on sections of the coast with very little urban and agricultural land (Hussein 2009; Smith 2013; Raabe and Stumpf 2015), whereas we mapped migration across the entire Chesapeake Bay region including areas that are highly urbanized. For example, the lowest marsh migration rates were observed for the Cape Charles map, where direct loss to coastal development negated any potential gains from migration. We found a weak relationship between migration rate and slope in uplands with minimal development (Fig. 5b). LiDAR-derived slope estimates may not be sufficiently accurate to identify correlations between slope and migration rate. In particular, our slope estimates are based on the slope of adjacent uplands, rather than the actual submerged upland over which the marshes have historically migrated. Nevertheless, regional-scale projections of marsh migration often rely on coarse elevation datasets and the assumption that migration occurs as soon as topography is inundated (Feagin et al. 2010; Morris et al. 2012; Clough et al. 2016; Enwright et al. 2016; Kirwan et al. 2016b). Our findings therefore suggest that there are important limitations to simple topographic inundation models and that more process-based studies are needed to discern the role of coastal development and ecological lags in marsh migration.

Observations of historical marsh stability in the Chesapeake region contribute to the growing body of evidence that migration into uplands is a primary component of marsh response to sea level rise at regional scales. Previous 
studies, for example, found that historical migration into uplands exceeded edge erosion for a section of the Florida Gulf coast (Raabe and Stumpf 2015). The area of land that could be inundated by $1 \mathrm{~m}$ of SLR is similar to the existing area of coastal wetlands in the coterminous USA (Morris et al. 2012), and modeling studies suggest that in the absence of anthropogenic barriers to migration, a moderate acceleration in sea level rise could actually lead to overall marsh expansion (Feagin et al. 2010; Cadol et al. 2016; Clough et al. 2016; Kirwan et al. 2016a). Our work is consistent with these studies, but uniquely suggests that when integrated over a region with both anthropogenic and topographic barriers, migration has allowed marshes to survive but not expand substantially.

Simple extrapolation of our results from the study area to the entire Chesapeake region suggests that sea level rise has led to massive and widespread drowning of uplands, which has created more than 100,000 acres $\left(400 \mathrm{~km}^{2}\right)$ of new marsh over the last century. Marsh migration into these drowned uplands has created about one third of all the marsh in the mapped region (marsh migration $=101 \mathrm{~km}^{2}$; total 2013 marsh area $=318 \mathrm{~km}^{2}$ ). Moreover, about one third of all marshes mapped in the late nineteenth century $\left(311 \mathrm{~km}^{2}\right)$ were lost by 2013 , presumably due to edge erosion $\left(94 \mathrm{~km}^{2}\right)$. These observations of rapid marsh change emphasize the disparity between marsh instability in the lateral dimension and marsh stability in the vertical dimension where marshes have survived low rates of sea level rise for thousands of years (Fagherazzi et al. 2013; Kirwan and Megonigal 2013). Traditional approaches to predicting and mitigating marsh vulnerability to sea level rise focus on the survival of existing marsh. However, our results indicate that sea level rise itself creates new marsh through upland drowning and that marsh size can be maintained despite substantial loss of existing marsh. Averaged across the Chesapeake Bay region, widespread upland drowning has historically compensated for marsh edge erosion and allowed Chesapeake Bay marshes to maintain their spatial extent despite relative sea level rise rates that are among the fastest in the world. There are real concerns over the ability of marshes to survive sea level rise in the Chesapeake and beyond (Kearney et al. 2002; Beckett et al. 2016; Crosby et al. 2016; Schepers et al. 2017; Watson et al. 2016), and our study focuses simply on the broad spatial extent of marshes rather than any indicator of their health. Nevertheless, our results emphasize that the location of coastal ecosystems changes rapidly on century timescales and that sea level rise does not necessarily lead to overall habitat loss.

Acknowledgements The Dominion Foundation, NSF Coastal SEES 1426981, NSF LTER 1237733, NSF CAREER 1654374, U.S. Department of Energy Terrestrial Ecosystem Science Program, and the USGS Climate and Land Use Dynamics Program funded this project. We would like to thank David Wilcox, Madison Clapsaddle, VIMS Center for Coastal Resources Management and VIMS Shoreline Studies programs, and the Chesapeake Bay National Estuarine Research Reserve
System for assistance with the GIS analyses. This is contribution number 3676 of the Virginia Institute of Marine Science.

\section{References}

Anisfeld, S.C., K.R. Cooper, and A.C. Kemp. 2017. Upslope development of a tidal marsh as a function of upland land use. Global Change Biology 23, 755-766. https://doi.org/10.1111/gcb.13398.

Balke, T., M. Stock, K. Jensen, T.J. Bouma, and M. Kleyer. 2016. A global analysis of the seaward salt marsh extent: The importance of tidal range. Water Resources Research 52: 3775-3786.

Barbier, E.B., S.D. Hacker, C. Kennedy, E.W. Koch, A.C. Stier, and B.R. Silliman. 2011. The value of estuarine and coastal ecosystem services. Ecological Monographs 81: 169-193.

Beckett, L.H., A.H. Baldwin, and M.S. Kearney. 2016. Tidal marshes across a Chesapeake Bay subestuary are not keeping up with sealevel rise. PLoS ONE 11(7): e0159753. https://doi.org/10.1371/ journal.pone.0159753.

Brinson, M.M., R.R. Christian, and L.K. Blum. 1995. Multiple states in the sea-level induced transition from terrestrial forest to estuary. Estuaries 18: 648-659.

Byrn, R.J., and G.L. Anderson. 1978. Shoreline erosion in tidewater Virginia. Special Report in Applied Marine Science and Ocean Engineering 111, Virginia Institute of Marine Science, Gloucester Pt, VA, 102. http://ccrm.vims.edu/gis_data_maps/shoreline inventories/virginia/scan_reports/TidewaterShorelineErosion.pdf.

Cadol, D., A. Elmore, S. Guinn, K.A.M. Engelhardt, and G. Sanders. 2016. Modeled tradeoffs between developed land protection and tidal habitat maintenance during rising sea levels. PLOS ONE 11(10): e0164875. https://doi.org/10.1371/journal.pone.0164875.

Cahoon, D.R., P.F. Hensel, T. Spencer, D.J. Reed, and N.S. McKee. 2006. Coastal vulnerability to relative sea-level rise: Wetland elevation trends and process controls. Ecological Studies 190: 271-292.

Chesapeake Bay Program: Tidal wetland abundance. 2015.http://www. chesapeakebay.net/indicators/indicator/tidal_wetlands abundance.

Church, J.A., P.U. Clark, A. Cazenave, J.M. Gregory, S. Jevrejeva, A. Levermann, M.A. Merrifield, G.A. Milne, R.S. Nerem, P.D. Nunn, A.J. Payne, W.T. Pfeffer, D. Stammer, and A.S. Unnikrishnan. 2013. Sea level change. In Climate change 2013: The physical science basis. Contribution of Working Group I to the Fifth Assessment Report of the Intergovernmental Panel on Climate Change, ed. T.F. Stocker, D. Qin, G.-K. Plattner, M. Tignor, S.K. Allen, J. Boschung, A. Nauels, Y. Xia, V. Bex, and P.M. Midgley. Cambridge, United Kingdom and New York, NY, USA: Cambridge University Press.

Clark, J.S. 1986. Coastal forest tree populations in a changing environment, southeastern Long Island, New York. Ecological Monographs 56: 259-277.

Clough, J., A. Polaczyk, and M. Popato. 2016. Modeling the potential effects of sea-level rise on the coast of New York: Integrating mechanistic accretion and stochastic uncertainty. Environmental Modelling \& Software 84: 349-362.

Collins, B.D., and A.J. Sheikh. 2005. Historical reconstruction, classification and change analysis of Puget Sound tidal marshes. Puget Sound River History Project Report to: Washington Department of Natural Resources. http://www.pugetsoundnearshore.org/ supporting_documents/historical_shoreline_dnr.pdf.

Corbett, D.R., J.P. Walsh, S.R. Riggs, D.V. Ames, and S.J. Culver. 2008. Shoreline change within the Albemarle-Pamlico estuarine system, North Carolina. 1907-2007 Centennial. https://www.ecu.edu/csacad/icsp/upload/EstuarineShorelineChangeDec2008.pdf.

Craft, C., J. Clough, J. Ehman, S. Joye, R. Park, S. Pennings, H. Guo, and M. Machmuller. 2009. Forecasting the effects of accelerated sea- 
level rise on tidal marsh ecosystem services. The ecological society of America. Frontiers in Ecology and the Environment 7 (2): 73-78.

Crosby, S.C., D.F. Sax, M.E. Palmer, H.S. Booth, L.A. Deegan, M.D. Berness, and H.M. Leslie. 2016. Salt marsh persistence is threatened by predicted sea-level rise. Estuarine, Coastal and Shelf Science 181: 93-99.

Curray, J.R. 2016. Transgressions and regressions. In Papers in marine geology, ed. R.L. Miller, 175-203. New York: Macmillan.

D’Alpaos, A., C. Da Lio, and M. Marani. 2012. Biogeomorphology of tidal landforms: Physical and biological processes shaping the tidal landscape. Ecohydrology 5: 550-562.

Day, J., C. Ibáñez, F. Scarton, D. Pont, P. Hensel, J. Day, and R. Lane. 2011. Sustainability of Mediterranean deltaic and lagoon wetlands with sea-level rise: The importance of river input. Estuaries and Coasts 34: 483-493.

Douglas, B., and M. Crowell. 2000. Long-term shoreline position prediction and error propagation. Journal of Coastal Research 16 (1): $145-152$.

Doyle, T.W., K.W. Krauss, W.H. Conner, and A.S. From. 2010. Predicting the retreat and migration of tidal forests along the northern Gulf of Mexico under sea-level rise. Forest Ecology and Management 259: 770-777.

Engelhart, S.E., B.P. Horton, B.C. Douglas, W.R. Peltier, and T.E. Törnqvist. 2009. Spatial variability of late Holocene and $20^{\text {th }}$ century sea-level rise along the Atlantic coast of the United States. Geology 37: 1115-1118.

Enwright, N.M., K.T. Griffith, and M.J. Osland. 2016. Barriers to and opportunities for landward migration of coastal wetlands with sealevel rise. Frontiers in Ecology and the Environment 14 (6): 307316.

ESRGC: Eastern Shore Regional GIS Cooperative LiDAR Services. 2015. http://lidar.salisbury.edu/arcgis/rest/services/DEM_ft.

Ezer, T., and W.B. Corlett. 2012. Is sea level rise accelerating in the Chesapeake Bay? A demonstration of a novel new approach for analyzing sea level data. Geophysical Research Letters 39, L19605. https://doi.org/10.1029/2012GL053435.

Fagherazzi, S., G. Mariotti, P. Wiberg, and K. McGlathery. 2013. Marsh collapse does not require sea level rise. Oceanography 26: 70-77.

Feagin, R., M. Martinez, G. Mendoza-Gonzalez, and R. Costanza. 2010. Salt marsh zonal migration and ecosystem service change in response to global sea level rise: A case study from an urban region. Ecology and Society 15(4): 14. [online] URL: http://www. ecologyandsociety.org/vol15/iss4/art14/.

Field, C.R., C. Gjerdrum, and C.S. Elphick. 2016. Forest resistance to sea-level rise prevents landward migration to tidal marsh. Biological Conservation 201: 363-369.

FitzGerald, D., M. Fenster, B. Argow, and I. Buynevich. 2008. Coastal impacts due to sea-level rise. Annual Review of Earth and Planetary Sciences 36: 601-647.

Ford, H., A. Garbutt, C. Ladd, J. Malarkey, and M.W. Skov. 2016. Soil stabilization linked to plant diversity and environmental context in coastal wetlands. Journal of Vegetation Science 27 (2): 259-268.

Friedrichs, C.T., and J.E. Perry. 2001. Tidal salt marsh morphodynamics: A synthesis. Journal of Coastal Research 27: 7-37.

Ganju, N.K., N.J. Nidzjeko, and M.L. Kirwan. 2013. Inferring tidal wetland stability from channel sediment fluxes: Observations and a conceptual model. Journal of Geophysical Research Earth Surface 118: 2045-2058.

Gedan, K.B., M.L. Kirwan, E. Wolanski, E.B. Barbier, and B.R. Silliman. 2011. The present and future role of coastal wetland vegetation in protecting shorelines: Answering recent challenges to the paradigm. Climatic Change 106 (1): 7-29.

Glick, P., J. Clough, and B. Nunley. 2008. Sea-level rise and coastal habitats in the Chesapeake Bay region. Technical Report. National Wildlife Federation. https://www.nwf.org/media/PDFs/Global-
Warming/Reports/SeaLevelRiseandCoastalHabitats ChesapeakeRegion.ashx.

Hussein, A.H. 2009. Modeling of sea-level rise and deforestation in submerging coastal ultisols of Chesapeake Bay. Soil Science Society of America Journal 73 (1): 185.

Kearney, M.S., E.G. Russell, and J.C. Stevenson. 1988. Marsh loss in Nanticoke Estuary, Chesapeake Bay. Geographical Review 78 (2): 205-220.

Kearney, M.S., and J.C. Stevenson. 1991. Island land loss and marsh vertical accretion rate evidence for historical sea-level changes in Chesapeake Bay. Journal of Coastal Research 7 (2): 403-415.

Kearney, M.S., A.S. Rogers, J.R.G. Townshend, E. Rizzo, and D. Stutzer. 2002. Landsat imagery shows decline of coastal marshes in Chesapeake and Delaware Bays. Eos, Transactions American Geophysical Union 83 (16): 173-184.

Kemp, A.C., B.P. Horton, S.J. Culver, D.R. Corbett, O. van de Plassche, W.R. Gehrels, B.C. Douglas, and A.C. Parnell. 2009. Timing and magnitude of recent accelerated sea-level rise (North Carolina, United States). Geology 37: 1035-1038.

Kirwan, M.L., and J.P. Megonigal. 2013. Tidal wetland stability in the face of human impacts and sea-level rise. Nature 504: 53-60.

Kirwan, M.L., S. Temmerman, E. Skeehan, G. Guntenspergen, and S. Fagherazzi. 2016a. Overestimation of marsh vulnerability to sea level rise. Nature Climate Change 6: 253-260.

Kirwan, M.L., G.R. Guntenspergen, A. D'Alpaos, J.T. Morris, S.M. Mudd, and S. Temmerman. 2010. Limits on the adaptability of coastal marshes to rising sea level. Geophysical Research Letters 37: L23401. https://doi.org/10.1029/2010GL045489.

Kirwan, M.L., J.L. Kirwan, and C.A. Copenheaver. 2007. Dynamics of an estuarine forest and its response to rising sea level. Journal of Coastal Research 232: 457-463.

Kirwan, M.L., and G.R. Guntenspergen. 2012. Feedbacks between inundation, root production, and shoot growth in a rapidly submerging brackish marsh. Journal of Ecology 100: 764-770.

Kirwan, M.L., D.C. Walters, W.G. Reay, and J.A. Carr. 2016b. Sea level driven marsh expansion in a coupled model of marsh erosion and migration. Geophysical Research Letters 43: 4366-4373.

Krauss, K.W., A.S. From, T.W. Doyle, T.J. Doyle, and M.J. Barry. 2011. Sea-level rise and landscape change influence mangrove encroachment onto marsh in the Ten Thousand Islands region of Florida, USA. Journal of Coastal Conservation 15: 629-638.

Marani, M., A. D'Alpaos, S. Lanzoni, and M. Santalucia. 2011. Understanding and predicting wave erosion of marsh edges. Geophysical Research Letters 38: L21401. https://doi.org/10.1029/ 2011 GL048995.

Mariotti, G., and S. Fagherazzi. 2010. A numerical model for the coupled long-term evolution of salt marshes and tidal flats. Journal of Geophysical Research 115, F01004. https://doi.org/10.1029/ 2009JF001326.

McLoughlin, S.M., P.L. Wiberg, I. Safak, and K.J. McGlathery. 2015. Rates and forcing of marsh edge erosion in a shallow coastal bay. Estuaries and Coasts 38 (2): 620-638.

Moore, L. 2000. Shoreline mapping techniques. Journal of Coastal Research 16 (1): 111-124.

Morris, J.T., J. Edwards, S. Crooks, and E. Reyes. 2012. Assessment of carbon sequestration potential in coastal wetlands. In Recarbonization of the biosphere, ed. R. Lal, K. Lorenz, R.F. Hüttl, B.U. Schneider, and J. von Braun, 517-531. Dordrecht: Springer Netherlands.

Multi-Resolution Land Characteristics Consortium. 2016. http://www. mrlc.gov/nlcd2011.php.

NOAA. NOAA Shoreline Website: NOAA Historical Surveys (TSheets). 2015. https://shoreline.noaa.gov/intro/.

Perry, J.E., T.A.J.R. Barnard, J.G. Bradshaw, C.T. Friedrichs, K.J. Havens, P.A. Mason, W.I. Priest III, and G.M. Silberhorn. 2001. 
Creating tidal salt marshes in the Chesapeake Bay. Journal of Coastal Research 27: 179-191.

Phillips, J.D. 1986. Spatial analysis of shoreline erosion, Delaware Bay, New Jersey. Annals of the Association of American Geographers 76 (1): 50-62.

Poulter, B., N. Christensen, and S. Qjian. 2008. Tolerance of Pinus taeda and Pinus serotine to low salinity and flooding: Implications for equilibrium vegetation dynamics. Journal of Vegetation Science 19 (1): 15-22.

Raabe, E.A., and R.P. Stumpf. 2015. Expansion of tidal marsh in response to sea-level rise: Gulf Coast of Florida, USA. Estuaries and Coasts 39 (1): 145-157.

Reed, D.J. 1995. The response of coastal marshes to sea-level rise: Survival or submergence? Earth Surface Processes and Landforms 20: 39-48.

Reed, D.J., D.A. Bishara, D.R. Cahoon, J. Donnelly, M. Kearney, A.S. Kolker, L.L. Leonard, R.A. Orson, and J.C. Stevenson. n.d.-bn.d.an.d.-an.d.2008-b. Site-specific scenarios for wetlands accretion as sea level rises in the Mid-Atlantic region. Section 2.1 in. Background Documents Supporting Climate Change Science Program Synthesis and Assessment Product 4.1., Titus, J.G., and Strange, E.M. (eds.). EPA 430R07004. U.S. EPA, Washington, DC.

Riggs, S.R. 2001. Shoreline erosion in North Carolina estuaries: The Soundfront Series UNC-SG_01-11. North Carolina Sea Grant, Raleigh, Pub. No. N.C., UNC-SG-01-11, 69.

Rosen, P.S. 1980. Erosion susceptibility of the Virginia Chesapeake Bay shoreline. Marine Geology 34: 45-59.

Sallenger, A.H.S., K.S. Doran, and P.A. Howd. 2012. Hotspot of accelerated sea-level rise on the Atlantic coast of North America. Nature Climate Change 2: 884-888.

Schepers, L., Kirwan, M., Guntenspergen, G., and Temmerman, S., 2017. Spatio-temporal development of vegetation die-off in a submerging coastal marsh. Limnology and Oceanography 62: 137-150.

Schwimmer, R.A. 2001. Rates and processes of marsh shoreline erosion in Rehoboth Bay, Delaware, U.S.A. Journal of Coastal Research 17 (3): 678-683.

Scott, M., L. McDermott, E. Silva, and E. Watson. 2009. Digital spatial data capture of marsh extent in Blackwater National Wildlife
Refuge, 1938 and 2006. Eastern Shore GIS Cooperative at Salisbury University.

Shalowitz, A.L. 1964. Shore and sea boundaries. Washington, DC: U.S. Government Printing Office.

Silliman, B., P. Dixon, C. Wobus, Q. He, P. Daleo, B. Hughes, J. Willis, and M. Hester. 2016. Thresholds in marsh resilience to the Deepwater Horizon oil spill. Scientific Reports 6: 32520. https:// doi.org/10.1038/srep32520.

Smith, J.A.M. 2013. The role of Phragmites australis in mediating inland salt marsh migration in a Mid-Atlantic Estuary. PLoS ONE 8(5): e65091. https://doi.org/10.1371/journal.pone.0065091.

Soil Conservation Service. 1975. Estuarine Shoreline Erosion Inventory, North Carolina. Raleigh, North Carolina: U.S. Soil Conservation Service, $71 \mathrm{p}$.

Stevenson, J.C., M.S. Kearney, and E.C. Pendleton. 1985. Sedimentation and erosion in a Chesapeake Bay brackish marsh system. Marine Geology 67: 213-235.

Torio, D.D., and G.L. Chmura. 2013. Assessing coastal squeeze of tidal wetlands. Journal of Coastal Research 29 (5): 1049-1061.

Virginia Lidar. 2015. http://virginialidar.com/index-3.html\#.V_Z1vkrKUk.

Wasson, K., A. Woolfolk, and C. Fresquez. 2013. Ecotones as indicators of changing environmental conditions: Rapid migration of salt marsh-upland boundaries. Estuaries and Coasts 36: 654-664.

Watson, E.B., K.B. Raposa, J.C. Carey, C. Wigand, and R.S. Warren. 2016. Anthropocene survival of southern New England's salt marshes, Estuaries and Coasts 40: 617-625.

Weston, N.B. 2014. Declining sediments and rising seas: An unfortunate convergence for tidal wetlands. Estuaries and Coasts 37: 1-23.

Williams, K., K.C. Ewel, R.P. Stumpf, F.E. Putz, and T.W. Workman. 1999. Sea-level rise and coastal forest retreat on the West Coast of Florida, USA. Ecology 80: 2045-2063.

Wrayf, R.D., S.P. Leatherman, and R.J. Nicholls. 1995. Historic and future land loss for upland and marsh islands in the Chesapeake Bay, Maryland, U.S.A. Journal of Coastal Research 11 (4): 11951202. 